PROCEEDINGS OF THE

AMERICAN MATHEMATICAL SOCIETY

Volume 129, Number 9, Page 2817

S 0002-9939(01)05540-X

Article electronically published on April 5, 2001

\title{
ADDENDUM TO "INDEPENDENCE AND DETERMINATION OF PROBABILITIES"
}

\author{
ZHIQIANG CHEN, HERMAN RUBIN, AND RICHARD A. VITALE \\ (Communicated by Clifford J. Earle, Jr.)
}

We have been apprised by A. P. Yurachkivsky that Theorem 1 of our paper [1] is contained in a result of his, as abstracted in "Axiomatization of stochastic independence" (5th International Vilnius Conference on Probability Theory and Mathematical Statistics, Abstracts of Communications, Vol. 4, 1989) and proved in preprint form as No. 90.6 "Axiomatic relations of independence as an equivalent of the probability measure" (Institute for Mathematics of the Academy of Science of the Ukrainian SSR, Kiev, 1990).

\section{REFERENCES}

1. Z. Chen, H. Rubin, and R. A. Vitale, Independence and determination of probabilities, Proc. Amer. Math. Soc. 125 (1997), 3721-3723. MR98b:60007

Department of Mathematics, William Paterson College, Wayne, New Jersey 07470

E-mail address: z.chen@smtplink.wilpaterson.edu

Department of Statistics, Purdue University, West Lafayette, Indiana 47907

E-mail address: hrubin@stat.purdue.edu

Department of Statistics, University of Connecticut, Storrs, Connecticut 06269

E-mail address: rvitale@uconnvm.uconn.edu

Received by the editors March 25, 1999.

1991 Mathematics Subject Classification. Primary 60A99; Secondary 28A99.

(C)2001 American Mathematical Society 